\title{
Quantifying the relationship between entrepreneurship and competitiveness development stages in Latin America
}

\author{
José Ernesto Amorós • Cristóbal Fernández • \\ Juan Tapia
}

Published online: 7 January 2011

(C) The Author(s) 2011. This article is published with open access at Springerlink.com

\begin{abstract}
This research aims to quantify the importance of a country's entrepreneurship level in terms of its competitiveness rates. Our hypothesis is that those countries entrepreneurship growth rates increase their competitiveness indicators and that this entrepreneurial improvement could be a key factor in reaching the next stage of development. We establish this relationship using a longitudinal database of Latin American countries that participated in the Global Entrepreneurship Monitor (GEM) and the Global Competitiveness Reports of the World Economic Forum (WEF) from 2001 to 2006. GEM and WEF construct aggregated indexes using several variables to rate each country's entrepreneurship activity and competitiveness development. We use a discriminant analysis to identify various countries' competitiveness subgroups and show how each country's entrepreneurship rates have weight in different stages of competitiveness, placing a special emphasis on Latin America. Our results suggest that Latin American countries need to gain entrepreneurial dynamics and economic (and competitiveness) development by transforming their typical self-employment or low value-added new ventures for local markets into strong, innovative networked firms competing globally. Some management and policy implications are also discussed.
\end{abstract}

Keywords Competitiveness · Economic growth · Global Entrepreneurship Monitor · Latin America · Discriminant analysis

J. E. Amorós $(\square)$

School of Business and Economics, Universidad del Desarrollo, Av. La Plaza 700. Las Condes, 7610658 Santiago, Chile

e-mail: eamoros@udd.cl

J. E. Amorós

ESADE Business School, Barcelona, Spain

C. Fernández $\cdot$ J. Tapia

Industrial Department, Universidad Técnica Federico Santa María, Av. España 1680, Valparaíso, Chile

J. Tapia

Department of Economics, University of California Davis, One shields Avenue, Davis, CA 95616, USA 


\section{Introduction}

Entrepreneurship is a very important activity for a country's competitiveness and growth and a significant source of social mobility. New ventures have become an important aspect of countries' economic development, especially in terms of their contributions to new job creation (Birch 1979, 1987). However, going beyond the relevant function of entrepreneurship in job generation, there is an important debate about the real impact that entrepreneurship has on countries' economic and competitiveness development (Acs and Storey 2004; van Stel et al. 2005; Acs and Amorós 2008). Ever since Schumpeter's (1934) seminal work on the role of entrepreneurs in identifying opportunities to create value by introducing innovation in the market, a considerable part of the literature suggests that entrepreneurship contributes to economic performance by introducing innovation, bringing about market changes, enhancing rivalry, and creating competition (Wong et al. 2005, p. 337).

Based on this discussion, it is evident that different countries or regions have varying relationships between their degree of entrepreneurial dynamics and their competitiveness stages. The influence of entrepreneurial dynamics ${ }^{1}$ on countries' competitive development (and consequently on their economic growth) presents a complex relationship (Spencer and Gómez 2006). For many emerging economies, such as that in Latin America, spurring economic growth through new business creation can be problematic at times (Fritsch and Mueller 2004). Over the last 20 years, many Latin American countries have experienced high economic growth rates. Natural resource exporting and certain low value-added products led to economic expansion in these countries until the mid-1990s; however, over the last few years, economic growth rates have slowed down considerably (Echecopar 2004; IADB 2006; IADB 2008). Porter (1990), who developed a position that differs from the principle of maximization for the use of natural resources, affirms that "The theory of the comparative advantage in factors is also frustrating for the companies because its assumptions bear scarcely any resemblance to real competition. A theory which overlooks the role of the companies' strategy, such as improving technology or differentiating products, leaves very little ways out for companies, except from trying to influence the policy of the government" (p. 35). On the other hand, when analyzing the factors related to technological innovation that determine the success of firms in underdeveloped or developing countries, Vignolo and Wechsler (1992) say that "In any serious consideration of the factors of competitiveness and the power of the countries in the international arena, it is necessary to bear in mind that nowadays having or not having natural resources appears as a completely irrelevant factor. To this must be added the fact that having natural resources with comparative advantages has become, for many underdeveloped countries, a real curse, against what common sense leads us to expect" (p. 2) This translates into an emerging interest on how Latin American countries could develop more new ventures to produce value-added products or services. With this rationale, entrepreneurship and

\footnotetext{
${ }^{1}$ It is possible to distinguish between the static and dynamic perspectives of entrepreneurship. The static perspective refers to the number of business owners as a dimension of the industrial structure of the economy. The dynamic perspective refers to the gross changes in the entrepreneurship rate (Wennekers et al. 2005, p. 295).
} 
innovation processes are key factors to increase economic dynamism (Minniti et al. 2006). Nevertheless, empirical studies regarding the impact of entrepreneurial activity on countries' competitive development are limited (van Stel et al. 2005), especially in developing countries (West et al. 2008).

As such, the objective of this research is to quantify the relationship between entrepreneurship and competitiveness development stages in a sample of Latin American countries. We define each country's entrepreneurship rates using a construct called the entrepreneurship factor. Our main hypothesis is that countries that evidence growth in entrepreneurship rates increase their competitiveness indicators, which is likely to be a key factor in reaching the next stage of development. In other words, countries that have a positive entrepreneurship factor have positive degree of competitiveness. We establish this relationship applying a discriminant analysis model to data from a longitudinal database of Latin American countries that participated in the Global Entrepreneurship Monitor (GEM) and the Global Competitiveness Reports of the World Economic Forum (WEF) from 2001 to 2006.

The rest of the paper is structured as follows: In Section 2, we discuss the literature related to Latin American competitiveness and entrepreneurship, and we state our hypothesis. In Section 3, we set forth the methodology and describe the variables under study. Section 4 presents the results followed by a discussion and conclusions in Section 5.

\section{A general framework of entrepreneurship and competitiveness: the Latin American perspective}

Entrepreneurship and competiveness at the country level

Competiveness at the country level is a wide topic that has been growing since the inception of Porter's (1990) arguments about the relevance of nations' competitive advantage. Some of the most well known examples of research on international comparisons of national competitiveness have been conducted for the World Economic Forum's Global Competitiveness Report and for IMD's World Competitiveness Yearbook. Following the World Economic Forum's framework, Porter et al. (2002) defined competitiveness according to a country's economic development, which was separated into three specific stages: the factor-driven stage, the efficiencydriven stage, and the innovation-driven stage. In addition, Porter et al. (2002) developed two transitions between these stages. The third stage of economic development defined by Porter has some similarities to the arguments presented by Audretsch and Thurik (2001, 2004) which suggest that "entrepreneurial economies" are linked closely to countries in the innovation-oriented stages, while countries with "managed economies" that are more closely linked to the efficiency-oriented stage.

Some studies arguing that during the last two decades, the development of new technologies and consequently the emergence of new business models have shifted from large corporations to small and new ventures (Audretsch and Thurik 2001; Thurow 2003; Wennekers et al. 2005). Domestic rivalry in the markets in which the firms compete generates pressure on the companies to improve and innovate. Rival companies show their animosity to each other by reducing costs and improving 
quality and services so as to create new and better products and processes. In this context, entrepreneurial dynamics are relevant because rivalry will also depend on setting up new firms to create new competitors. This "entrepreneurship process" could be vital for competitive advantage because it nurtures the innovation process in an industrial sector. The new entrepreneurial businesses may serve new segments or try new methods that their rivals who have been on the scene longer failed to identify or respond to for lack of flexibility. These entrepreneurial firms help nations' innovation systems, allowing them to adapt to the changing conditions of global competitiveness and provides them with the capacity to establish differences in order to increase the value acknowledged by their markets. Innovative and entrepreneurial value-added products and services have direct and indirect effects on competitive advantages instead comparative advantages based on raw materials or labour force.

For example, in Latin America some countries that export more complex products enjoy more prosperity than those that only export commodities or those that are based on comparative advantages alone. For these reasons, countries' competitiveness (not only in Latin America but elsewhere as well) has an important relationship with several indicators at the microeconomics and business firm level. As Porter (2002) elaborates, they are "microeconomic foundations of the economy, rooted in the company operating practices and strategies as well as in the quality of the inputs, infrastructure, institutions, and array of regulatory and other policies that constitute the business environment in which a nations' firms compete" (p. 1). These microlevel indicators include entrepreneurship activities. The level of a country's development (competitiveness and economic) encourages and strengthens entrepreneurial activity (Acs et al. 2005), but at the same time, entrepreneurship contributes to these developments. Recently, the Global Entrepreneurship Monitor (GEM) project based on the Global Competitiveness Report pointed out that certain framework conditions relate more fully to innovation-driven economies that are specific to innovation and new venture creation (Bosma and Levie 2010). In this sense, entrepreneurship is the mechanism that turns innovation into economic output (Acs and Armington 2006; Bosma and Levie 2010).

Despite the fact that entrepreneurial efforts could improve competitiveness and economic growth - namely, they could help countries transition from "managed economies" to "entrepreneurial economies"- there is evidence that shows that entrepreneurship dynamics differ not only among countries with different development stages (Carree et al. 2002; van Stel et al. 2005; Carree et al. 2007) but also among regions in a single country (Audretsch and Keilbach 2004; Lee et al. 2004; Belso-Martínez 2005). Empirical studies based on information gathered from different countries in different time periods ${ }^{2}$ reveal various types of relationships

\footnotetext{
${ }^{2}$ Some works, like Tang and Koveos (2004), van Stel et al. (2005), Wennekers et al. (2005), Acs and Amorós (2008), and Amorós and Cristi (2008), have shown a different relationship between entrepreneurship rates and different economic and competitive performance variables. Furthermore, Carree et al. (2002) showed a U-shaped relationship between the level of per capita income and the rate of self-employment (or business ownership) in 23 OECD countries and revisited their research founding an L-shape for the entrepreneurship equilibrium rate (Carree et al. 2007). Wennekers et al. (2005) also showed three U-shaped links between entrepreneurship rates and the level of economic development, measured in terms of income per capita, innovation capacity, and diverse associated socio-demographic variables.
} 
between the variables that measure the level of entrepreneurship, economic growth, and competitiveness (Wennekers et al. 2010). These differences depend on specific conditions at the national or regional level, which, in turn, are related to many aspects that include socio-cultural, institutional, and economics factors (Valliere and Peterson 2009). Regarding the three stages of economic development, the GEM Project remarks:

It is important to recognize that the three principal types of economic activity: factor-driven, efficiency-driven, and innovation-driven, are present in all national economies. But their relative prevalence-and their contribution to economic development - varies. The Global Competitiveness Report proposition is that each phase of economic development has different optimal combination of these activities. The three phases are labelled according to the activity that is most significant for that phase. Thus the relative importance of entrepreneurial framework conditions to a country's advancement in economic development may vary by phase of economic development. (Bosma and Levie 2010, p. 11)

To summarise these ideas, entrepreneurship varies across countries and depends not only on economic growth but also on other factors, such as institutional characteristics, socio-demographic factors, etc., that are correlated in very complex systems. However, most researchers agree that entrepreneurship activities matter for economic development (Bosma and Levie 2010), even though these activities have different scopes or respond to different conditions depending the degree or level of the country's competitiveness.

\section{The "entrepreneurial reality" and "entrepreneurial paradox" in Latin America}

There is a consensus that Latin America is a region with great economic potential. With a population about 569 million people and an aggregate gross domestic product of about $\$ 6.6$ billion $^{3}$ U.S. Dollars (2009, PPP), the region also is home of two of the largest economies in the world: Brazil and Mexico. Many Latin American countries have been reformed in the last 20 years, including privatizations, increases in the role of private enterprises in fostering economic growth, and high-powered incentives for efficient enterprises (Aulakh et al. 2000). Additionally, the region has made real efforts in the area of democracy, property rights, and macroeconomic stability. Without prejudice to the above facts, in comparative terms, some emergent economies, such as Israel, Korea, Singapore, and Ireland, have experienced a remarkable transformation in the last 20 years both in terms of economic growth and institutional development. At the same time, Latin America has shown much lower levels of development. Some causes of this relatively poor performance are that the region still lags in the "softer" areas of education, knowledge creation, and economic reform. Therefore, the region has been less successful in improving economic performance compared to other emerging markets (Blejer 2006; López-Claros et al. 2006) and has had more difficulties developing other "softer" activities, like entrepreneurship and new business creation (Acs and Amorós 2008).

\footnotetext{
${ }^{3}$ Millions of millions
} 
The entrepreneurship phenomenon in Latin America has become a rapidly expanding field (Kantis et al. 2002; Kantis 2004; Amorós and Cristi 2008). Tiffin (2004) demonstrates the increasing interest and numerous implications of entrepreneurship topics in almost all of the countries in the region. In addition, Latin American policymakers are increasingly emphasizing entrepreneurial activities, including new business creation and self-employment, because these activities have the potential to significantly enhance social and economic development. ${ }^{4}$ Peres and Stumpo (2002) show that new and small firms are not only secondary actors in the industrial structure of the countries because new ventures can create jobs (or employ individuals in the case of self-employment), but they can also help "rejuvenate" regional economies (Capelleras et al. 2010).

Latin American countries have great potential to generate competitiveness and wellbeing through the creation of new firms; however, they have generally been unable to consolidate entrepreneurial dynamics (Kantis 2005). The GEM methodology 5 places Latin American participant countries as having high entrepreneurship rates. Compared with the average rates of efficiency-driven economies and also with those of innovation-driven nations, the average rates of early-stage entrepreneurship activity $^{6}$ in Latin America are significantly high, as exhibited in Fig. 1. For example, some early-stage entrepreneurship activity rates in Peru or Bolivia were around 25\% 2005 to 2008. These quantitative indicators reflect the fact that many adults are directly involved in entrepreneurship activities. Nevertheless, the dynamism of new Latin American ventures is lower by comparison to other emergent regions, such as Southeast Asia, because according GEM data (and other related studies), the region has high necessity-based entrepreneurship rates (Kantis et al. 2004; Autio 2005, 2007; Minniti et al. 2006; Bosma and Levie 2010). In relative terms, necessity-motivated entrepreneurs take part in a large share of the total entrepreneurial activity in Latin America. However, many of these "entrepreneurial activities" include self-employment, which cannot provide value-added business opportunities or subsequent growth. Necessitydriven entrepreneurial businesses are not bad outcomes, as they could be a "reaction" (push motives) to certain national conditions. Necessity-driven entrepreneurial businesses could be beneficial for many economies because in many cases, despite the extremely small scale of the business, they can still be a productive source of employment. As discussed previously, many factors, such as institutional environment, influence the entrepreneurships dynamics in Latin America. These weak institutional environments have created informal, lifestyle, and survivalist entrepreneurs (de Soto 1989), but they could also be a barrier for the subsequent growth of these new firms (Capelleras and Rabetino 2008).

\footnotetext{
${ }^{4}$ In the $1990 \mathrm{~s}$, when the region achieved a moderate of growth, the labour market "left" the micro and small enterprises to moved to big established firms (about $90 \%$ of the total new jobs), but micro and smalls firms also playing a safety-valve role when no other employment sources were available (Berry 2002).

${ }^{5}$ For the methodological design and implementation of the GEM project, see Reynolds et al. (2005).

${ }^{6}$ In the methodology section, we detail how early-stage entrepreneurial activity is calculated in terms of a percentage of the adult population who are setting up a business or are owner-managers of a new business that has paid any form of salary or wages for fewer than 42 months.
} 


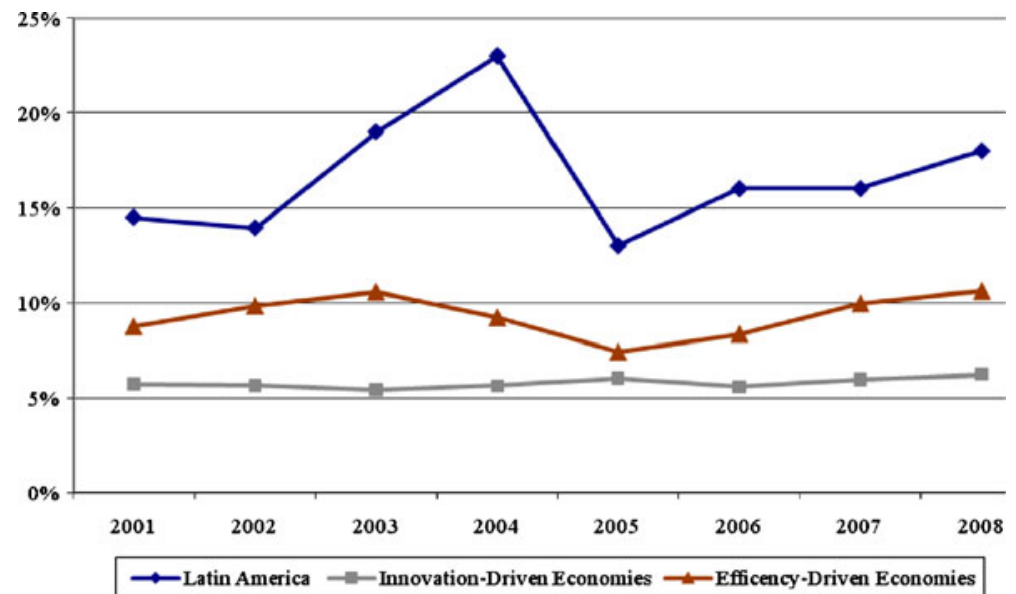

Source: Developed by the authors based on GEM database

Fig. 1 Early-stage entrepreneurship rates between Latin America and other groups of economies (20012008)

So, here is the paradox: Latin American countries have relatively "poor performance" in competitiveness and entrepreneurial dynamics but have a large number of entrepreneurs. Most developed countries and other emergent regions (the "East Asian miracle") have transitioned from the efficiency-driven stage to the innovation-driven stage (the entrepreneurial society), which is characterised by knowledge spillovers, increased competition, and diversity among major firms (Acs and Amorós 2008). These factors allow flexibility and innovation in the economy, in which new firms are crucial for technological improvement and innovation. As a rule, following Audretsch and Thurik's (2004) arguments, Latin American countries display features of a "managed economy" in which most of the small-scale production firms have minor significance in innovation, and the products and services offered are of minimal value in comparison to those of large and concentrated companies. Latin American economies have a limited number of nascent ventures necessary for an "entrepreneurial economy" on account of the many restrictions present for creating knowledge-based businesses (Angelelli and Kantis 2004). Furthermore, empirical evidence has shown that the transition between two economic models is slower for Latin American countries than for industrialized countries. For economies in the innovation-driven stage, new firms are crucial in terms of technological improvement and innovation (Porter et al. 2002). Based on the WEF Competitiveness Reports, López-Claros et al. (2006) classify Latin American and Caribbean countries in these different competitiveness stages. We will address this classification in our analysis of the results.

In sum, we hypothesize that entrepreneurship is a very important variable with enormous importance for countries' growth, especially in Latin America. Furthermore, its importance increases as countries grow in term of competitiveness and economic growth and move on to new stages of development that require a systematic and clear structure for support and promotion. 


\section{Methodology}

\section{Background information}

Both "The World Competitiveness Yearbook" and "The Global Competitiveness Report" (GCR) make indexes showing how different countries rank in terms of competitiveness over time and classify these countries hierarchically in terms of a series of variables representing both the micro- and macroeconomic influences each country has in the world. Both reports present each country's competitive situation in terms of individual variables and combination of variables. For instance, GCR calculates its index by a country's weighted average across three major indicators: basic requirements (institutions, infrastructure, macroeconomics, health, and primary education), efficiency enhancers (higher education and training, market efficiency, and technological readiness), and innovation and sophistication factors (business sophistication and innovation). ${ }^{7}$ The weightings used are shown in Table 1 , and their classifications as different states are shown in Table 2.

\section{Data}

Using the GCR data, we wanted to determine the differences that influence specific countries' indicators and explore which factors have relative priority over others in enabling countries to attain their competitiveness goals. Therefore, we analyzed the weight of the relative importance attributable to each variable and/or factor for each country and explained any set of variables with a high level of correlation. On the other hand, we believe that entrepreneurship is a key factor for countries to achieve their competitiveness-level goals; therefore, it became imperative to consider what variables are directly related to the entrepreneurship phenomena in our analysis of the ordinal classification of the variables.

Our analysis includes 71 sub-indexes from the GCR (Appendix 1) for 71 countries (Appendix 2) between 2001 and 2006. These variables are based on the Executive Opinion Survey developed by the WEF. This survey is based on the opinions of business executives who not only have broad familiarity with the current conditions in their countries but also knowledge and experience in the global environment. The survey asks the participants from approximately 125 counties to evaluate each variable on a scale of 1 to 7 with 1 representing the worst possible condition and 7 the best possible condition. With this objective, the WEF contacted about 130 partner institutions from around the world. For each year the survey was implemented, the WEF received approximately 11,000 and 12,000 responses. $^{8}$ In addition, to classify the countries, we used information about GDP per capita that was also reported by the GCR. This information allowed us to classify the countries into the following groups: 1) countries with a per capita income GDP lower than US

\footnotetext{
${ }^{7}$ This classification corresponds to that offered by The Global Competitiveness Index for 2006-2007 because year after year, they have changed the way in which they calculate the index, creating inconsistencies in the index.

${ }^{8}$ The World Economics Forum subjects raw data to a rigorous quality control process.
} 
Table 1 Weightings used by the World Economic Forum for calculating the competitiveness index

\begin{tabular}{lccc}
\hline Weights & $\begin{array}{l}\text { Basic } \\
\text { requirements }\end{array}$ & $\begin{array}{l}\text { Efficiency } \\
\text { enhancers }\end{array}$ & $\begin{array}{l}\text { Innovation and } \\
\text { sophistications factors }\end{array}$ \\
\hline Factor-driven stage & $50 \%$ & $40 \%$ & $10 \%$ \\
Efficiency-driven stage & $40 \%$ & $50 \%$ & $10 \%$ \\
Innovation-driven stage & $30 \%$ & $40 \%$ & $30 \%$ \\
\hline
\end{tabular}

Source: The Global Competitiveness Report 2006-2007

$\$ 3,000,2)$ countries with a per capita GDP income between US\$ 6,000 and US\$ 9,000 , and 3) countries with a per capita income higher than US\$9,000

Factor analysis

The main problem with the three indexes used by GCR is how the components are weighted. The weight assigned to each sub-index is based on subjective criteria. This could to some sub-indexes being overweighed or underweighted. Therefore, it would be useful to determine the classification of the most relevant variables for explaining competitive performance and those that incorporate the entrepreneurship factor as a priority factor. Additionally, we needed to establish some type of "behaviours" for Latin American cases specifically. With the purpose of finding common structures among these variables independent from the categories that GCR defines, we applied a factor analysis model to identify a lower number of underlying structures. The common variables defined by the GCR in their competitiveness reports for the 2001-2006 period enabled us to identify 71 variables that belong to the aforementioned generic groups.

Discriminant analysis

After grouping the variables into factors, the second step was quantitatively analyzing the influence of the macroeconomic and entrepreneurship variables. To accomplish this task, we considered it necessary to use a model that enables us to establish the differences in weight of importance that each factor contributes to nations' ability to attain prosperity; therefore, we apply a discriminant analysis

Table 2 Match of the different states according to GDP per capita

Stage of development

GDP per capita (in US\$)

Stage 1: Factor-driven stage

$<2000$

Transition from stage 1 to stage 2

2000-3000

Stage 2: Efficiency-driven stage

3000-9000

Transition from stage 2 to stage 3

9000-17,000

Stage 3: Innovation-driven stage

$>17,000$

Source: The Global Competitiveness Report 2006-2007 
model. Discriminant analysis is useful because it allows for characterization and classification; in this case, it enabled us to identify and classify a group of countries ${ }^{9}$ (Moreno and Casillas 2007).

\section{Categorical dependent variable}

The levels of GDP per capita were used to determine the different levels at which the factors will be differentiated. As proposed by Porter (2005) and in line with GCR's methodology, we used the gross domestic product per capita to differentiate among the different countries depending on their level of growth because it "will reflect a country's structural fundamentals over the middle and long term" (p. 51). ${ }^{10}$ For the discriminant analysis, we ranked the countries as follows: countries with a per capita income GDP lower than a US $\$ 3,000$, countries with a per capita GDP income between US\$ 6,000 and US\$9,000, and countries with a per capita income higher than US $\$ 9,000$. These rates are adjusted by the purchasing power parity, GDP per capita (PPP). The data was taken from the International Monetary Fund's World Economic Outlook Database. ${ }^{11}$

\section{Independent variables}

First, we used the factors obtained by the factor analysis procedure. Next, the analysis was repeated using the specific indicators for entrepreneurship (instead of the factors) from the GEM database for 2001-2006. At the end of 2006, 55 different countries had participated in GEM, 10 of which are from the Latin American and Caribbean region. The GEM provides harmonized, internationally comparable data on entrepreneurial activity ${ }^{12}$ and contains various entrepreneurial measures that are constructed on a survey basis ${ }^{7}$, known as the Adult Population Survey. The GEM estimates the percentage of the adult population (people between 18-64 years old) that is actively involved in starting a new venture and separates them into two categories: 1) nascent entrepreneurs who have taken action to create a new business in the past year but have not paid any salaries or wages for more than 3 months and 2) owner/managers of a business who have paid wages and salaries for over three months but for fewer than 42 months. The sum of these measurements is known as Total Entrepreneurship Activity (TEA) Index. In addition, the individuals involved in TEA are classified ${ }^{13}$ into Opportunity Entrepreneurs (people that want to exploit a perceived business opportunity) and Necessity Entrepreneurs (people that did not

\footnotetext{
$\overline{{ }^{9} \text { Other techniques could be also }}$ used, such as logistic regression techniques for instance. Nevertheless, discriminant analysis and logistic regression techniques generally reveal the same pattern and produce similar solutions, especially when we used with a dichotomous dependent variable, as in this case. One interesting future extension would be to compare those solutions. Due to the expected similarity of both techniques' results in this case, the difference among them would not have affected our conclusions.

${ }^{10}$ Appendix 1 shows the countries grouped into five categories using the GCR criteria. We highlighted the countries from Latin America and the Caribbean.

${ }^{11}$ Available online at http://www.imf.org/external/data.htm.

${ }^{12}$ More details about the GEM project, data, and reports may be obtained at http://www.gemconsortium. org.

${ }^{13}$ For the complete GEM project measurements, see Reynolds et al. (2005), and for recent changes to the GEM measurements, see Minniti et al. (2006) and Bosma et al. (2008).
} 
have a better option for work as an employee). We use Opportunity and Necessity rates in our analysis.

\section{Results}

The factor analysis by means of the orthogonal rotation method yielded four factors that account for $75.4 \%$ of the variance ${ }^{14}$ as a whole. The decision to work with four factors was made based on the criteria of stopping the analysis before the eigenvalue becomes greater than 1 . We also did several analyses with a different number of factors, but this did not provide any more information. In addition, the variables included in these other cases did not allow us to complete a conceptual analysis with the same form as the other four cases.

Factor 1 is the main factor, accounting for more than $65 \%$ of the variance:

Factor 1 is considered the enterprising, efficiency, and innovation factor. Some variables considered in this factor include the capacity for innovation, local availability of specialized research and training services, companies spending on research and development, production-process sophistication, value-chain presence, the nature of competitive advantage, the quality of management schools, and the availability of venture capital, among others.

Factor 2 groups the variables that are related to stability and best practices within the public and private sector and government, such as cooperation in labour-employer relations, government effectiveness in reducing poverty, public trust of politicians, favouritism in government officials' decisions, government surplus/deficit, irregular payments in public contracts, and irregular payments in export and imports.

Factor 3 is comprised of variables including both the financial sector as well as government promotion of investments in science and technology, such as government success in ICT promotion, government prioritization of ICT, access to credit and FDI, and technology transfer.

Factor 4 includes mainly variables that are associated mainly to macroeconomic stability, such as national savings ratios, inflation, and interest ratios.

If we compare our factors with the original factors utilized by the World Economic Forum, Basic Requirements (Institutions, Infrastructure, Macroeconomics, Health, and Primary Education) would be separated in our case between factors 2 and 4; Efficiency Enhancers (Higher Education and Training, Market Efficiency, and Technological Readiness) and Innovation and Sophistication Factors (Business Sophistication and Innovation) are both part of factors 1 and 3. As we explained before, the necessity of grouping factors in this form was originally due to the fact that the weight of each factor variable was based on subjective criteria; however, this new arrangement allows us to group these variables based on the correlation between each one, thereby enabling us to avoid underestimating or overestimating the weight of each variable. Additionally, this categorization allows us to keep the conceptual value of each factor, as the factor analysis enabled us to group each variable with a clear conceptual relationship.

\footnotetext{
${ }^{14}$ Both the Bartlett tests as well as the Kaiser-Meyer-Olkin (KMO) show that the results are statistically significant. $\mathrm{KMO}=0.970$; Barlett Test $p=0.000,(n=432)$.
} 
Appendix 2 lists the resulting factors and the variables constituting them.

To analyze our hypothesis about the importance of innovation and the entrepreneurship in countries' growth, it is important to determine the weight of factors 1 and 3 on the competitiveness of a country and to analyze the importance of the enterprising factors within the frame of each country's entrepreneurship and competitiveness. First, we show maps that face the position of each Latin American country considered in our sample has with respect to those factors (see Figs. 2 and 3). Second, we quantified the weight of each factor using the discriminant method.

- Figures 2 and 3 are useful to obtain a reference for each factor in relative terms to the total sample; the rest of the points shown on these figures represent the other countries considered in the WEF's data (most of the Latin American countries are positioned in the negative quadrant of the map for these factors). Some countries, such as Argentina, Brazil, Costa Rica, Mexico, Chile, and Panama, all of which have a GDP per capita ranging between US\$3,000 and US\$9000, have a better relative position for these factors; however, other countries, such as Bolivia, Paraguay, Nicaragua, and Honduras that have a GDP per capita lower than US\$2,000. This shows - at least based on the first qualitative impression- $-\mathrm{a}$ positive relationship between the innovation and entrepreneurship variables and Latin American countries' success in term of growth. This could be important information in terms of the relevant factors for the development process of these countries.

Having obtained the four factors, we resorted to a linear discriminant analysis, a tool yielding a discriminant function that statistically discriminates between three groups of cases (successful countries, countries having intermediate success, and

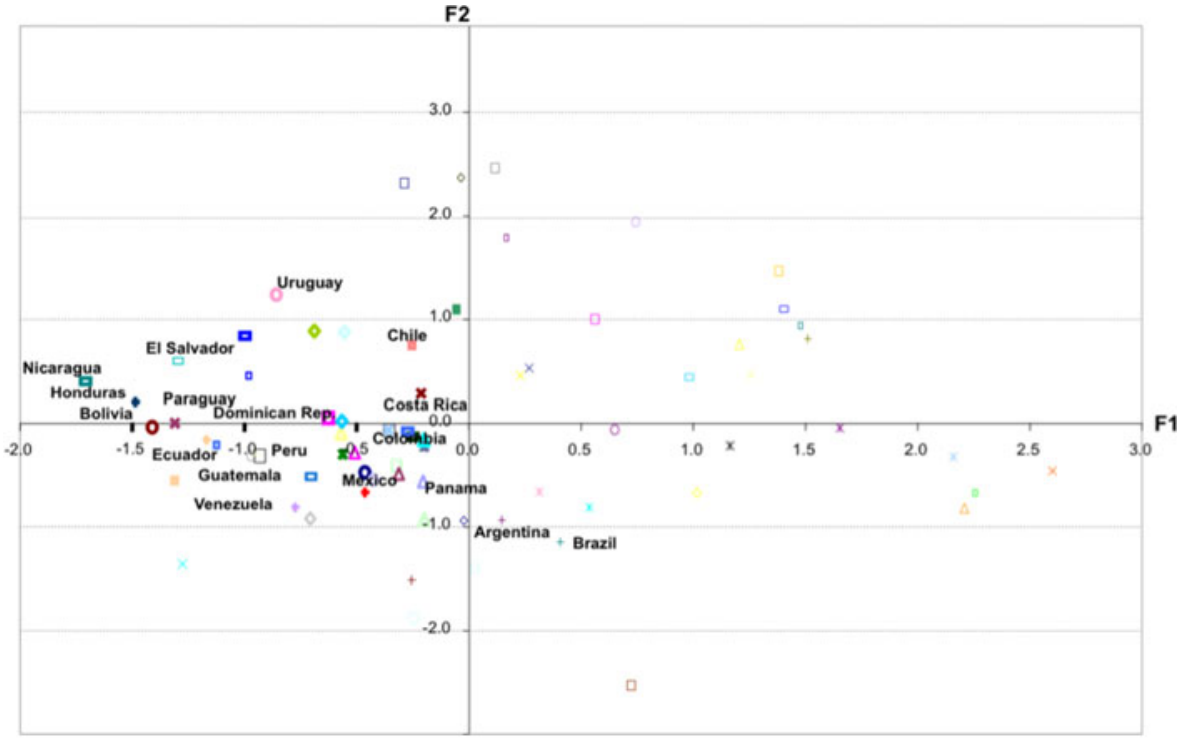

Source: Developed by the authors

Fig. 2 Map positioning of Factor 1 (enterprising and innovation factor) vs. Factor 2 (stability and good practices within the public and private sector) 


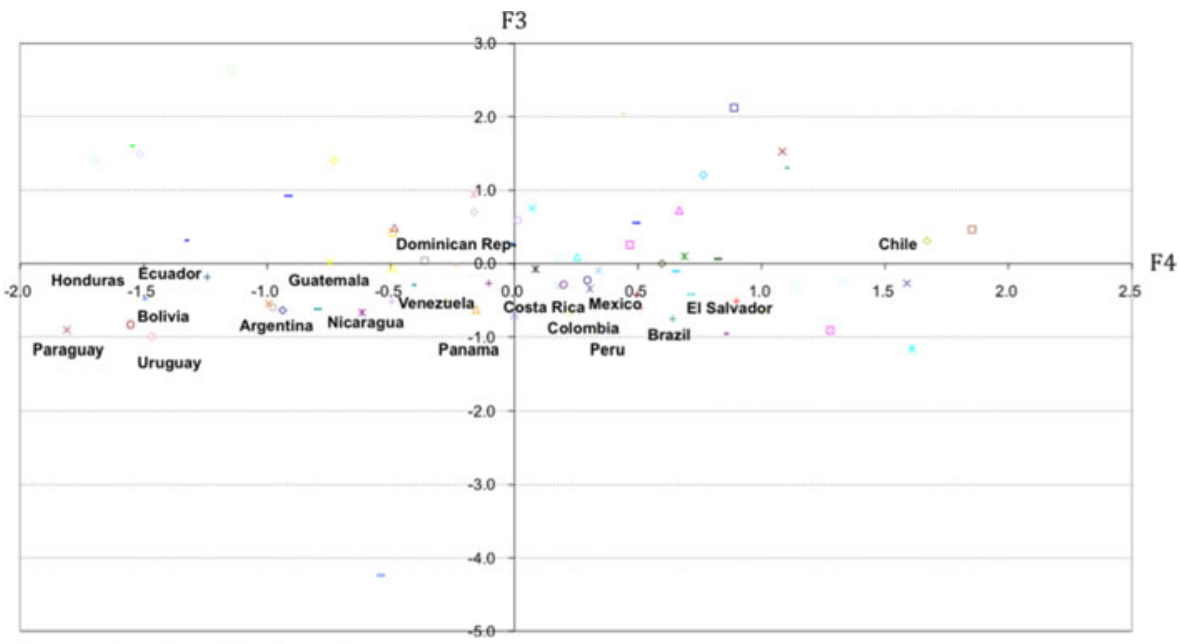

Source: Developed by the authors

Fig. 3 Map positioning of Factor 3 (financial sector and the government's promotion of investments in science and technology) vs. Factor 4 (macroeconomic stability)

countries with a moderate degree of performance ${ }^{15}$ ). This technique fits well with a country's capacity to generate its GDP per capita ${ }^{16}$ The analysis was performed for two purposes: on the one hand, it seeks to obtain a classification of the factors' data within the predetermined discriminatory groups, and secondly, it enables us to quantify the factors that better describe an association with one of the groups (namely, which factors have a greater discriminant weight), allowing us to quantify the importance of the factors related to entrepreneurship. In this analysis, we used the Wilkins's method, which elects variables for the model and defines the order of inclusion. $^{17}$

After applying the variables obtained in the factor analysis to this procedure, the procedure yielded two significant factors when it came to discriminating between the different stages: factors 1 and 3 (Table 3). The results of the structural matrix are shown in Table 4. These results show that the two factors are associated with entrepreneurship and innovation variables. The degree of significance is good for

\footnotetext{
$\overline{15}$ To classify these three cases, we used the three groups of countries classified by GDP indicated in section 3.1: countries with a per capita income GDP lower than a US\$3,000, countries with a per capita GDP income between US $\$ 6,000$ and US $\$ 9,000$, and countries with a per capita income higher than US $\$ 9,000$. These rates are adjusted by the purchasing power parity per US dollars, GDP per capita (PPP).

${ }^{16}$ See the methodology developed by Zirger and Maidique (1990, p.867-883).

${ }^{17}$ This method resorts to the lambda $(\lambda)$, which represents the sum of the ratio between the sum of the intra-group squares with a reference to the average or centroid of the values under analysis. When the values of this coefficient are close to 1 , the mean average groupings of a same factor or variable are equal and tend to be 0 when total the variability is attributable to differences between groups. In addition to the Wilks indicator, we also used other indicators, such as the $F$ associated to a level of significance, which represents the ratio average between the variance between groups and the average intra-group (an average intra-group is expressed as the variance between the degrees of freedom and the average intra-group variance and the degrees of freedom or variance that such a variable or factor has). Referential methods indicate whether the level of significance is lower than 0.005 , the hypothesis that states that the mean averages are equal, is rejected. In turn, for a statistical test, an $F$ associated is used to determine whether the contribution made by the new factor is significant or not.
} 
Table 3 Wilks' lambda

\begin{tabular}{lllllllll}
\hline & & \multicolumn{7}{c}{ Exact $F$} \\
\cline { 5 - 8 } & Statistic & $\mathrm{df1}$ & $\mathrm{df2}$ & $\mathrm{df3}$ & Statistic & Df1 & $\mathrm{df2}$ & Sig. \\
\hline Factor 1 & .500 & 1 & 2 & 429.000 & 214.674 & 2 & 429.000 & .000 \\
Factor 3 & .287 & 2 & 2 & 429.000 & 185.317 & 4 & 856.000 & .000 \\
\hline
\end{tabular}

both factors chosen by the procedures as discriminating factors. This finding is accordance with respect to the variables associated with macro-economic stability, as they are constantly increasing in weight in a qualifying manner (as opposed to a differentiating manner) with respect to both factors chosen as discriminating factors. Table 5 shows the classification results; we found that $75 \%$ of the originally grouped cases were correctly classified, and $74.8 \%$ of the cross-validated grouped cases were correctly classified.

An aspect that is well worth mentioning is how the importance of each factor evolves between the different stages. Factor 1, which corresponds to the innovation and entrepreneurship variables, is relevant as a country move from the first to the second stage, but it becomes even more relevant as the country passes from stage 2 to stage 3 . Among these variables are those that are said to support entrepreneurial activities both from a financial as well as a governmental standpoint, as these findings enable us to deduce the increasing importance of innovation and entrepreneurship factors as the country develops in economic terms, not only in a spontaneous manner, but also within a frame that has been designed in accordance with this progress.

Based on these results, a new discriminant analysis was performed using the stages that were mentioned earlier, though for a sample of 29 countries during the last 6 years. For this analysis, we used the indicators entrepreneurship factor out of necessity (NEC) and due to opportunity (OPP) based on the classification generated by the Global Entrepreneurship Monitor. The results of the structural matrix are shown in Table 6.

Most importantly, the necessity-based entrepreneurship variable shows the best level of significance, close to 0. However, the opportunity-based entrepreneurship variable did not have any significantly statistical results, which is to be expected given the size of the sample and the number of stages. Nevertheless, there appears to be a marked difference between the different types of entrepreneurship with respect to the level of development that a given country has attained thus far. To be consistent with what we said initially, in the sense that there are two types of entrepreneurship - spontaneous self-entrepreneurship and structured entrepreneurship_-both are positively associated with countries' growth.

Table 4 Structure matrix for different development stages according discriminating significant factors

\begin{tabular}{llr}
\hline & Function & \\
\cline { 2 - 3 } & 1 & 2 \\
\hline FACTOR 1 & 0.632 & -0.772 \\
FACTOR 3 & 0.42 & 0.907
\end{tabular}


Table 5 Classification results ${ }^{\mathrm{b}, \mathrm{c}}$

\begin{tabular}{|c|c|c|c|c|c|c|}
\hline & & \multirow[t]{2}{*}{ For discriminant } & \multicolumn{3}{|c|}{ Predicted Group Membership } & \multirow[t]{2}{*}{ Tota } \\
\hline & & & 0 & 1 & 2 & \\
\hline \multirow[t]{6}{*}{ Original } & \multirow[t]{3}{*}{ Count } & 0 & 87 & 33 & 5 & 125 \\
\hline & & 1 & 41 & 79 & 7 & 127 \\
\hline & & 2 & 0 & 22 & 158 & 180 \\
\hline & \multirow[t]{3}{*}{$\%$} & 0 & 69.6 & 26.4 & 4.0 & 100 \\
\hline & & 1 & 32.3 & 62.2 & 5.5 & 100 \\
\hline & & 2 & 0.0 & 12.2 & 87.8 & 100 \\
\hline \multirow[t]{6}{*}{ Cross-validated $^{\mathrm{a}}$} & \multirow[t]{3}{*}{ Count } & 0 & 87 & 33 & 5 & 125 \\
\hline & & 1 & 41 & 79 & 7 & 127 \\
\hline & & 2 & 0 & 23 & 157 & 180 \\
\hline & \multirow[t]{3}{*}{$\%$} & 0 & 69.6 & 26.4 & 4.0 & 100 \\
\hline & & 1 & 32.3 & 62.2 & 5.5 & 100 \\
\hline & & 2 & 0.0 & 12.8 & 87.2 & 100 \\
\hline
\end{tabular}

${ }^{\text {a }}$ Cross validation is only done for those cases in the analysis. In cross validation, each case is classified by the functions derived from all cases other than that case

b $75.0 \%$ of original grouped cases correctly classified

c $74.8 \%$ of cross-validated grouped cases correctly classified

\section{Discussion and conclusions}

Today, in Latin American countries, there are several challenges one of which is discovering what steps need to be taken to arrive at a greater level of development. When we face this question, it is important to discover what factors are more important in a country's development. Every government faces different alternatives to their development - different possible policies and resources; therefore, they have to choose which factors have the greatest potential of helping their development based on the moment at hand. As such, this study is an important contribution, as it gives quantitative weight to different types of variables, groups these variables with clear criteria, and demonstrates the increased importance of the variables associated with entrepreneurship and innovation as countries grow

Our results provide evidence as to the importance of competitiveness and the entrepreneurship factor in Latin American countries. The most developed countries, especially those countries with a GDP per capita between US $\$ 3,000$ and US $\$ 9,000$, are in a special position to achieve more progress in their competitiveness stages. Furthermore, for those countries with a per capita GDP below US\$3,000, their

Table 6 Structure matrix for different development stages according to the types of entrepreneurship

\begin{tabular}{llc}
\hline & Function & \\
\cline { 2 - 3 } & 1 & 2 \\
\hline NEC & .982 & .189 \\
OPP & .153 & .988
\end{tabular}


infrastructures for education, health, and telecommunications and their government stability are the "major issues" needing to be addressed, and they also need to improve their entrepreneurial environment as an additional factor that could contribute to their eventual competitiveness and economic growth. The GEM reports establish that countries with low incomes have a high rate of entrepreneurial activity derived from the fact that a large part of the population has not been alternative sources of employment. This phenomenon is a major factor in Latin American entrepreneurship rates (Llisterri et al. 2006). In this case, when middle-sized and large companies that operate in conventional industries are strengthened and when they have managed to become a source of employment, they can attract necessity-based entrepreneurs.

In this sense, Latin American governments not only need to emphasize macroeconomic variables, which continue to be important with a qualifying role rather than a differentiating role, but they also need to begin prioritizing their development by taking into account microeconomic variables (i.e., those more related to entrepreneurial economics) as well as by encouraging entrepreneurship activity in their countries. Figures 1 and 2 illustrate how several Latin American countries are adopting measures along these lines, as they have found these variables to be are important for greater growth. It is also a matter of concern to determine why certain countries have limited growth in per capita GDP, as this would aid in eventually diminishing the gaps in growth. Latin America has much room for growth in the areas of entrepreneurship and microeconomic stability, which makes it indispensable for researchers to explore how a country's competitiveness depends on the competitiveness of the companies that are integral parts of each country. In turn, researchers also need to examine the development of "entrepreneurial cultures" (Malecki 1997; West et al. 2008) that enhance this potential of growth.

Our results using the discriminant analysis help to understand better the relationship between competitiveness and entrepreneurship. Our analysis illustrate that factors associated with entrepreneurial variables that are statistically significant with respect to their importance in different countries' development stages and also enabled us to detect the greater presence of necessity-based entrepreneurship in the first stages.

These results forced us to question whether entrepreneurship is truly relevant for Latin American economies or not. We believe that this question is not only relevant but also highly necessary. The implications to develop entrepreneurial activity in Latin America go beyond achieving an efficiency-driven economy stage. The region needs to develop more dynamic new ventures that reflect better competitiveness and economic-development performance (Autio 2005; Amorós and Cristi 2008).

As a restricting element to our research, we have, on the one hand, limited data for a great number of countries over a period limited period of time related to indicators directly associated with entrepreneurship. On the other hand, there is also disaggregation of the different types of entrepreneurship in the countries various areas of development. Also, we analyzed all of the countries together, as we believe the factors would have the same weight in each case. Along this line, it would be interesting to undertake an analysis on a country-by-country basis within the Latin American context to see how entrepreneurship has evolved and which policies may be adopted by each government according to their stage of development. Another interesting future extension would be to undergo a cluster analysis that allows categorizing the countries based on their characteristics to discover the best possibilities to use in each case. 
This study opens several new paths for research and discussion, and the results could also be helpful for making policies decisions to improve innovation and entrepreneurship in Latin America and also to justify the importance of promoting policies and projects along these lines.

Open Access This article is distributed under the terms of the Creative Commons Attribution Noncommercial License which permits any noncommercial use, distribution, and reproduction in any medium, provided the original author(s) and source are credited.

\section{Appendix 1}

Table 7 Factor analysis, rotated component matrix

\begin{tabular}{|c|c|c|c|c|}
\hline \multirow[b]{2}{*}{ Variable } & \multicolumn{4}{|l|}{ Factor } \\
\hline & 1 & 2 & 3 & 4 \\
\hline Capacity for innovation & 0.896 & 0.277 & 0.01 & 0.197 \\
\hline Government procurement of advanced technology products & 0.647 & 0.309 & 0.294 & 0.429 \\
\hline Local availability of process machinery & 0.829 & -0.003 & -0.112 & 0.333 \\
\hline Availability of scientists and engineers & 0.65 & 0.173 & 0.15 & 0.329 \\
\hline Railroad infrastructure development & 0.764 & 0.214 & 0.012 & 0.325 \\
\hline Firm-level technology absorption & 0.669 & 0.286 & 0.381 & 0.293 \\
\hline Brain drain & 0.625 & 0.447 & 0.155 & 0.265 \\
\hline Compliance effects on business & 0.679 & 0.429 & 0.274 & 0.257 \\
\hline University/industry research collaboration & 0.804 & 0.359 & 0.177 & 0.245 \\
\hline Quality of public schools & 0.657 & 0.497 & 0.122 & 0.242 \\
\hline Degree of customer orientation & 0.76 & 0.342 & 0.294 & 0.235 \\
\hline Intensity of local competition & 0.705 & 0.153 & 0.452 & 0.227 \\
\hline Company spending on research and development & 0.864 & 0.285 & 0.1 & 0.223 \\
\hline Value-chain presence & 0.834 & 0.227 & 0.104 & 0.216 \\
\hline Local supplier quantity & 0.849 & 0.099 & 0.262 & 0.214 \\
\hline Quality of scientific research institutions & 0.821 & 0.282 & 0.218 & 0.204 \\
\hline Internet access in schools & 0.641 & 0.541 & 0.279 & 0.199 \\
\hline Port infrastructure quality & 0.656 & 0.503 & 0.175 & 0.196 \\
\hline Quality of competition in the ISP sector & 0.639 & 0.401 & 0.225 & 0.189 \\
\hline Buyer sophistication & 0.806 & 0.313 & 0.33 & 0.187 \\
\hline Country credit rating, 2003 & 0.748 & 0.435 & 0.216 & 0.186 \\
\hline Production-process sophistication & 0.852 & 0.388 & 0.154 & 0.173 \\
\hline Clarity and stability of regulations & 0.724 & 0.553 & 0.187 & 0.159 \\
\hline Local availability of specialized research and training services & 0.877 & 0.289 & 0.139 & 0.153 \\
\hline Judicial independence & 0.664 & 0.484 & 0.336 & 0.148 \\
\hline Overall infrastructure quality & 0.721 & 0.535 & 0.2 & 0.145 \\
\hline Property rights & 0.685 & 0.484 & 0.415 & 0.13 \\
\hline Control of international distribution & 0.828 & 0.225 & 0.142 & 0.125 \\
\hline Air-transport infrastructure quality & 0.66 & 0.414 & 0.36 & 0.119 \\
\hline Presence of demanding regulatory standards & 0.817 & 0.43 & 0.25 & 0.118 \\
\hline
\end{tabular}


Table 7 (continued)

\begin{tabular}{|c|c|c|c|c|}
\hline \multirow[b]{2}{*}{ Variable } & \multicolumn{4}{|l|}{ Factor } \\
\hline & 1 & 2 & 3 & 4 \\
\hline Local supplier quality & 0.862 & 0.311 & 0.274 & 0.112 \\
\hline Laws relating to ICT & 0.696 & 0.464 & 0.405 & 0.111 \\
\hline Nature of competitive advantage & 0.835 & 0.356 & 0.023 & 0.101 \\
\hline Venture-capital availability & 0.701 & 0.404 & 0.378 & 0.101 \\
\hline Extent of regional sales & 0.661 & 0.335 & 0.249 & 0.096 \\
\hline Extent of staff training & 0.83 & 0.382 & 0.269 & 0.079 \\
\hline Intellectual property protection & 0.77 & 0.529 & 0.267 & 0.039 \\
\hline Stringency of environmental regulations & 0.785 & 0.493 & 0.195 & 0.035 \\
\hline Willingness to delegate authority & 0.771 & 0.457 & 0.246 & 0.033 \\
\hline Effectiveness of antitrust policy & 0.811 & 0.345 & 0.349 & -0.009 \\
\hline Extent of marketing & 0.829 & 0.233 & 0.356 & -0.026 \\
\hline Reliance on professional management & 0.743 & 0.342 & 0.387 & -0.028 \\
\hline Quality of management schools & 0.734 & 0.272 & 0.373 & -0.067 \\
\hline Extent of incentive compensation & 0.744 & 0.255 & 0.322 & -0.071 \\
\hline Financial-market sophistication & 0.722 & 0.381 & 0.433 & -0.103 \\
\hline Efficacy of corporate boards & 0.598 & 0.406 & 0.409 & -0.08 \\
\hline Local equity market access & 0.607 & 0.146 & 0.547 & 0.058 \\
\hline Ease of access to loans & 0.578 & 0.496 & 0.451 & 0.023 \\
\hline Extent of bureaucratic red tape & -0.428 & -0.281 & -0.122 & 0.011 \\
\hline Cooperation in labour-employer relations & 0.284 & 0.59 & 0.199 & 0.398 \\
\hline Government effectiveness in reducing poverty & 0.539 & 0.555 & 0.253 & 0.302 \\
\hline Public trust of politicians & 0.516 & 0.694 & 0.221 & 0.262 \\
\hline Favouritism in decisions of government officials & 0.586 & 0.643 & 0.261 & 0.171 \\
\hline Government surplus/deficit, 2002 & 0.024 & 0.532 & -0.043 & 0.155 \\
\hline Irregular payments in public contracts & 0.582 & 0.718 & 0.172 & 0.06 \\
\hline Business costs of corruption & 0.611 & 0.616 & 0.321 & 0.016 \\
\hline Irregular payments in tax collection & 0.535 & 0.684 & 0.069 & 0.006 \\
\hline Irregular payments in export and imports & 0.557 & 0.684 & 0.175 & -0.029 \\
\hline Organized crime & 0.21 & 0.357 & 0.094 & 0.058 \\
\hline Informal sector & -0.52 & -0.561 & -0.212 & -0.252 \\
\hline Government success in ICT promotion & 0.457 & 0.296 & 0.486 & 0.453 \\
\hline Government prioritization of ICT & 0.45 & 0.28 & 0.456 & 0.442 \\
\hline Access to credit & 0.21 & 0.168 & 0.686 & 0.215 \\
\hline FDI and technology transfer & 0.021 & 0.018 & 0.622 & 0.186 \\
\hline Soundness of banks & 0.46 & 0.435 & 0.559 & -0.098 \\
\hline Recession expectations & 0.169 & 0.079 & 0.538 & 0.45 \\
\hline National savings rate, 2002 & 0.063 & 0.049 & -0.024 & 0.73 \\
\hline Pay and productivity & 0.253 & 0.355 & 0.352 & 0.563 \\
\hline Hiring and firing practices & -0.147 & 0.302 & 0.123 & 0.527 \\
\hline Inflation, 2002 & -0.078 & 0.004 & -0.032 & -0.494 \\
\hline Interest rate spread, 2002 & -0.18 & -0.03 & -0.162 & -0.514 \\
\hline
\end{tabular}




\section{Appendix 2}

Table 8 List of countries at each stage of development

\begin{tabular}{|c|c|c|c|c|}
\hline \multicolumn{2}{|l|}{ Phase 0} & \multirow{2}{*}{$\begin{array}{l}\text { Phase } 1 \\
\begin{array}{l}\text { Stage } 2 \\
\text { efficiency-driven stage }\end{array}\end{array}$} & \multicolumn{2}{|l|}{ Phase 2} \\
\hline $\begin{array}{l}\text { Stage } 1 \\
\text { factor-driven stage, }\end{array}$ & $\begin{array}{l}\text { Transition } \\
\text { from } 1 \text { to } 2\end{array}$ & & $\begin{array}{l}\text { Transition } \\
\text { from } 2 \text { to } 3\end{array}$ & $\begin{array}{l}\text { Stage } 3 \\
\text { innovation-driven stage; }\end{array}$ \\
\hline Bangladesh & Colombia & Argentina & Czech Republic & Australia \\
\hline Bolivia & Ecuador & Brazil & Estonia & Austria \\
\hline China & El Salvador & Bulgaria & Hungary & Belgium \\
\hline Guatemala & Peru & Chile & Korea & Canada \\
\hline Honduras & Thailand & Costa Rica & & Denmark \\
\hline India & & Dominican Republic & & Finland \\
\hline Indonesia & & Jamaica & & France \\
\hline Nicaragua & & Latvia & & Germany \\
\hline Nigeria & & Lithuania & & Greece \\
\hline Paraguay & & Malaysia & & Hong Kong SAR \\
\hline Philippines & & Mauritius & & Iceland \\
\hline Sri Lanka & & Mexico & & Ireland \\
\hline Ukraine & & Panama & & Israel \\
\hline Vietnam & & Poland & & Italy \\
\hline \multirow[t]{12}{*}{ Zimbabwe } & & Romania & & Japan \\
\hline & & Russia & & Netherlands \\
\hline & & Slovak Republic & & New Zealand \\
\hline & & South Africa & & Norway \\
\hline & & Turkey & & Portugal \\
\hline & & Uruguay & & Singapore \\
\hline & & Venezuela & & Slovenia \\
\hline & & & & Spain \\
\hline & & & & Sweden \\
\hline & & & & Switzerland \\
\hline & & & & United Kingdom \\
\hline & & & & United States \\
\hline
\end{tabular}

Source: Based on the categories in the Global Competitiveness Report 2006-2007

\section{References}

Acs, Z. J., \& Amorós, J. E. (2008). Entrepreneurship and competitiveness dynamics in Latin America. Small Business Economics, 31(3), 305-322.

Acs, Z., \& Armington, C. (2006). Entrepreneurship, geography and American economic growth. Cambridge: Cambridge University Press.

Acs, Z. J., \& Storey, D. J. (2004). Introduction: entrepreneurship and economic development. Regional Studies, 38(8), 871-877. 
Acs, Z. J., Arenius, P., Hay, M., \& Minniti, M. (2005). Global entrepreneurship monitor: 2004 executive report. Wellesley: Babson College and London Business School.

Amorós, J. E., \& Cristi, O. (2008). Entrepreneurship and competitiveness development: a longitudinal analysis of Latin American countries. International Entrepreneurship and Management Journal, 4(4), 381-399.

Audretsch, D., \& Keilbach, M. (2004). Entrepreneurship and regional growth: an evolutionary interpretation. Journal of Evolutionary Economics, 14(5), 605-616.

Audretsch, D., \& Thurik, R. (2001). What is New about the New Economy? Sources of growth in the managed and entrepreneurial economy. Industrial and Corporate Change, 10(1), 267-315.

Audretsch, D., \& Thurik, R. (2004). Model of the entrepreneurial economy. The Papers on Entrepreneurship, Growth and Public Policy, Max Planck Institute, Jena 17.

Aulakh, P., Kotabe, M., \& Teegen, H. (2000). Export strategies and performance of firms from emerging economies: Evidence from Brazil, Chile and Mexico. Academy of Management Journal, $43,342-361$.

Autio, E. (2005). GEM report on high-expectation entrepreneurship. Babson Park: Babson College and London Business School.

Autio, E. (2007). GEM 2007: Global report on high-growth entrepreneurship. Babson Park: Babson College and London Business School.

Belso-Martínez, J. A. (2005). Equilibrium entrepreneurship rate, economic development and growth. Evidence from Spanish regions. Entrepreneurship \& Regional Development, 17(2), 145-161.

Berry, A. (2002). The role of the small and medium enterprise sector in Latin America and similar developing economies. Seton Hall Journal of Diplomacy and International Relations, Winter/Spring, $104-119$.

Birch, D. (1979). The job generation process. Cambridge, MA: MIT Program on Neighborhood and Regional Change.

Birch, D. (1987). Job creation in America: How our smallest companies put the most people to work. New York: The Free Press.

Blejer, M. (2006). Latin America and the external environment: A missed opportunity? In A. LópezClaros (Ed.), The Latin America competitiveness review 2006 (pp. 43-46). Geneva: World Economic Forum.

Bosma, N., \& Levie, J. (2010). Global entrepreneurship monitor, 2009 global report. Wellesley: Babson College.

Bosma, N., Jones, K., Autio, E., \& Levie, J. (2008). Global entrepreneurship monitor, executive report 2007. Wellesley: Babson College and London Business School.

Capelleras, J.-L., \& Rabetino, R. (2008). Individual, organizational and environmental determinants of new firm employment growth: evidence from Latin America. International Entrepreneurship and Management Journal, 4(4), 79-99.

Capelleras, J.-L., Greene, F., Kantis, H., \& Rabetino, R. (2010). Venture creation speed and subsequent growth: evidence from South America. Journal of Small Business Management, 48(3), $302-324$.

Carree, M., Van Stel, A., Thurik, R., \& Wennekers, S. (2002). Economic development and business ownership: an analysis using data of 23 OECD countries in the period 1976-1996. Small Business Economics, 19(3), 271-290.

Carree, M., Van Stel, A., Thurik, R., \& Wennekers, S. (2007). The relationship between economic development and business ownership revisited. Entrepreneurship and Regional Development, 19(3), 281-291.

De Soto, H. (1989). The other path: The invisible revolution in the Third World. New York: Harper \& Row.

Echecopar, G. (2004). Incubating innovative starts-ups: Some lesson for Chile. In S. Tiffin (Ed.), Entrepreneurship in Latin America, 2004 (pp. 101-112). Westport: Praeger.

Fritsch, M., \& Mueller, P. (2004). Effects of new business formation on regional development over time. Regional Studies, 38(8), 961-975.

IADB (2006). Annual inform 2005. In J. Ferriter (Ed.), Washington, D.C.: Inter-American Development Bank.

IADB (2008). Annual inform 2007. In A. Russell (Ed.), Washington, D.C.: Inter-American Development Bank.

Kantis, H. (2004). Main contrasts between Latin America and East Asia, Italy, and Spain. In H. Kantis, P. Angelelli, \& V. Moori-Koenig (Eds.), Experience in Latin America and Worldwide 2004 (pp. 57-74). Washington, DC: Inter-American Development Bank-Fundes International. 
Kantis, H. (2005). The emergence of dynamic ventures in Latin America, Southern Europe and East Asia: an international comparison. International Journal of Entrepreneurship and Small Business, 2(1), 34-56.

Kantis, H., Ishida, M., \& Komori, M. (2002). Entrepreneurship in emerging economies: the creation and development of new firms in Latin America and East Asia. Washington, DC: Inter-American Development Bank.

Kantis, H., Angelelli, P., \& Moori-Koenig, V. (2004). Experience in Latin America and Worldwide. Washington, DC: Inter-American Development Bank-Fundes International.

Lee, S. Y., Florida, R., \& Acs, Z. J. (2004). Creativity and entrepreneurship: a regional analysis of new firm formation. Regional Studies, 38(8), 879-891.

Llisterri, J. J., Kantis, H., Angelelli, P., \& Tejerina, L. (2006). Is youth entrepreneurship a necessity or an opportunity? A first exploration of household and new enterprise surveys in Latin America. Washington, DC: Sustainable Development Department Technical Papers Series, Inter-American Development Bank.

López-Claros, A., Altinger, L., Blanke, J., Drzeniek, M., \& Mía, I. (2006). Assessing Latin American competitiveness: Challenges and opportunities. In A. López-Claros (Ed.), The Latin America competitiveness review 2006 (pp. 3-36). Geneva: World Economic Forum.

Malecki, E. J. (1997). Entrepreneurs, networks, and economic development: A review of recent research. In J. K. Katz (Ed.), Advances in entrepreneurship, emergence and growth (pp. 57-118). Greenwich: JAI.

Minniti, M., Bygrave, W. D., \& Autio, E. (2006). Global entrepreneurship monitor executive report 2005. Babson Park: Babson College and London Business School.

Moreno, A. M., \& Casillas, J. C. (2007). High-growth SMEs versus non-high-growth SMEs: a discriminant analysis. Entrepreneurship \& Regional Development, 19(1), 69-88.

Peres, W., \& Stumpo, G. (2002). Las pequeñas y medianas empresas industriales en América Latina y el Caribe. CEPAL: Siglo Veintiuno Editores.

Porter, M. (1990). The competitive advantage of nations. New York: The Free Press.

Porter, M. (2002). Enhancing the Microeconomic Foundations of Prosperity: The Current Competitiveness Index in World Economic Forum, The Global Competitiveness Report 2001-2002 (pp. 2-26). Oxford: Oxford University Press.

Porter, M. (2005). Building the microeconomic foundations of prosperity: findings from the Business Competitiveness Index. In A. Lopez-Claros, M. Porter \& K. Schwab (Eds.), Global Competitiveness Report 2005-2006. Policies underpinning rising prosperity (pp 43-77). New Hampshire: Palgrave Macmillan.

Porter, M., Sachs, J., \& Arthur, J. (2002). Executive summary: Competitiveness and stages of economic development. In M. Porter, J. Sachs, P. K. Cornelius, J. W. McArthur, \& K. Schwab (Eds.), The global competitiveness report 2001-2002 (pp. 16-25). New York: Oxford University Press.

Reynolds, P., Bosma, N., Autio, E., Hunt, S., De Bono, N., Servais, I., et al. (2005). Global entrepreneurship monitor: Data collection design and implementation 1998-2003. Small Business Economics, 24(3), 205-231.

Schumpeter, J. A. (1934). The theory of economic development. Cambridge: Harvard University Press.

Spencer, J. W., \& Gómez, C. (2006). The relationship among national institutional structures, economic factors, and domestic entrepreneurial activity: a multicountry study. Journal of Business Research, 57 (10), 1098-1107.

Tang, L., \& Koveos, P. E. (2004). Venture entrepreneurship, innovation entrepreneurship and economic growth. Journal of Developmental Entrepreneurship, 9(2), 161-171.

Thurow, L. (2003). Fortune favours the bold: What we must do to build a new and lasting global prosperity. New York: Harper Collins.

Tiffin, S. (2004). Entrepreneurship in Latin America. Westport: Praeger.

Valliere, D., \& Peterson, R. (2009). Entrepreneurship and economic growth: evidence from emerging and developed countries. Entrepreneurship \& Regional Development, 21(5), 459-480.

Van Stel, A., Carree, M., \& Thurik, R. (2005). The effect of entrepreneurial activity on national economic growth. Small Business Economics, 24(3), 311-321.

Vignolo, C., \& Wechsler, G. (1992). La Innovación Tecnológica en Chile: lecciones de un estudio de caso de empresas manufactureras exitosas. Santiago: Universidad de Chile, Facultad de Ciencias Físicas y Matemáticas, Departamento de Ingeniería Industrial.

Wennekers, S., van Stel, A., Thurik, R., \& Reynolds, P. (2005). Nascent entrepreneurship and the level o economic development. Small Business Economics, 24(3), 293-309.

Wennekers, S., van Stel, A., Carree, M., \& Thurik, R. (2010). The relationship between entrepreneurship and economic development: is it U-shaped? Foundations and Trends in Entrepreneurship, 6(3), 167-237. 
West, G. P., III, Bamford, C. E., \& Marsden, J. W. (2008). Contrasting entrepreneurial economic development in emerging Latin American economies: Applications and extensions of resource-based theory. Entrepreneurship Theory and Practice, 32(1), 15-36.

Wong, P. K., Ho, Y. P., \& Autio, E. (2005). Entrepreneurship, innovation and economic growth: Evidence from GEM data. Small Business Economics, 24(3), 335-350.

Zirger, B., \& Maidique, M. (1990). A model of new product development: an empirical test. Management Science, 36(7), 867-883. 